Marquette University

e-Publications@Marquette

Social and Cultural Sciences Faculty Research and

Publications

Social and Cultural Sciences, Department of

$11-1-2001$

Building the Clinton Legacy Through Frame Alignment

Roberta Coles

Marquette University, roberta.coles@marquette.edu

Accepted version. Cultural Studies - Critical Methodologies, Vol. 1, No. 4 (November 2001): 459-487. DOI. (C) 2001 SAGE Publications. Used with permission. 


\title{
Building the Clinton Legacy Through Frame Alignment
}

\author{
By Roberta L. Coles
}

This article examines Clinton's rhetorical strategy for creating a legacy in light of the imminent end of his second and final term as president. By examining Clinton's public discourse from 1997 to 1999, with special attention to the period from September 1998 to June 1999, this article argues that Clinton used the frame of his race initiative to centripetally incorporate varied events and policies to redefine and bolster his legacy in the aftermath of scandal and political polarity. Specifically, President Clinton, with an eye on the legacy of the president and the identity of the Democratic Party, gathered the war in Kosovo and the shootings in Littleton, Colorado, along with their attendant disparate policies into one rhetorical frame, thereby supplying a conception of what Clinton's 6 years as president had been about, a vision and mission for America, and an identity for the Democratic party distinct from the Republicans.

Throughout 1998 and into 1999, President Bill Clinton was in the midst of, what Murray Edelman (1988) has termed, a political spectacle_a drama "comprised of effective and ineffective leaders managing the effort to cope with distressing problems and to defend the polity against external and internal enemies" (p. 120). The discovery and investigation of President Bill Clinton's affair with Monica Lewinsky, wrapped in the cloaks of moral disdain and political bipartisanship, was hurdling toward an impeachment trial. In his second and final term as president, Clinton was faced with questions from reporters about what, if anything, he had accomplished as president. ${ }^{1}$ Had his loss of moral authority rendered him ineffective in foreign affairs? What legacy would he leave behind? Had the value of any achievement been obliterated by the Lewinsky scandal? Would he only go down in history as a liar? The media speculated about what effect "Clinton fatigue" would have on Vice President Al Gore's chances for the presidency, Hillary Clinton's run for the Senate, and on the Democratic Party as a whole. ${ }^{2}$

Such spectacles impinge on private lives-not only of those directly involved in the spectacle but also of the spectators who become visually and emotionally entwined through the ongoing media event. Fundamentally, the myriad public selves were asking not only of President Clinton but also of themselves, first, "Who is Bill Clinton?" and, second, "Should an immoral person be president?" Does Bill Clinton have a single or mono-identity—that of a philanderer? And, if so, how important is that to the role of president? We now know that Clinton was not the first president to frolic amorously in the White House (and he probably will not be the last), so for some the more theoretical question concerning the appropriate relationship between private and 
public issues, between personal morality and public affairs, became the issue in this spectacle. As both a target of the spectacle and a player in it, Clinton could and did perform a reflexive interpretative role in answering these questions.

This article explores how Clinton's public discourse during the spectacle abstracted shared meanings from current foreign and domestic issues to create a presidential legacy and vision for the country in light of his diminishing image and the imminent end of his second and final term as president. By examining Clinton's public speeches from 1997 to 1999, with special attention to the period from September 1998 to June 1999 (the period of the end of the president's race initiative through the war in Kosovo), I provide an analysis of the creation of meaning developed incrementally in Clinton's public discourse, all of which is in the form of press conferences, speeches, and questionand-answer sessions found in the Weekly Compilation of Presidential Documents (hereinafter referred to as WCPD).

I argue that Clinton's framing of the race initiative, which lasted 18 months from June 1997 to September 1998, modifies in such a way to centripetally incorporate various events and policies. Together, these form a unifying master frame that essentially ignores the Lewinsky spectacle and simultaneously redefines and bolsters his questionable legacy in the aftermath of scandal and political polarity. Specifically, toward the end of 1998 and through mid-1990, Clinton's discourse gathered the war in Kosovo and the shootings in Littleton, Colorado, along with their attendant disparate policies (such as hate crime legislation and gun control), into one rhetorical frame of "overcoming the fear of difference," thereby supplying a conception of what Clinton's 6 years as president had been about, a vision and mission for America, and an identity for the Democratic Party distinct from the Republicans.

\section{The Rhetorical Presidency}

In general, the role of the president in the signifying process has increased over the 20th century. According to Ceaser, Thurow, Tulis, and Bessette (1981) and Tulis (1987), we are living in the age of the rhetorical presidency, as popular rhetoric on the part of the president, once infrequently employed, now serves as a principle tool in governing. Indeed, at times speaking is a substitute for governing, as reflected in political scientist Mary Stuckey's (1991) retitling of the presidency as "interpreter-in-chief." Acknowledging the president's persuasive powers and relative ease of access to media, Edelman (1988) has concluded that political language has become political reality.

More specifically, the role of the rhetorical president is twofold. First, the president helps people make sense-in ways that serve presidential interests, of course - of events occurring 
within the nation or of events occurring outside the nation that require deliberation about the nation's position and role in regard to those events. The ways in which a president frames such events inevitably imply or suggest an identity for the nation and/or for the political party she or he hopes will lead the nation. The identity or image that leaders frequently seek to bestow on the nation is one of virtue (Anderson, 1983; Browne, 1991). The virtuous nature of the nation, which must be revised over time to accommodate new historical circumstances (Slotkin, 1992), often depends on the collaboration of the people to be fulfilled (Browne, 1991). Hence, the president often implores the nation to join him in a virtuous mission, which, one can easily infer, may fail if the nation rejects such an invitation (Coles, 1998).

Second, as Kenneth Burke (1969, p. 391) pointed out, the president, faced with a multitude of piecemeal situations, must find some unitary principle from which all his major policies consistently radiate. What, then, might have appeared to the public as small, disorganized battles on various unrelated fronts appears instead as a coherent controlled agenda. This principle, at minimum, must give the appearance of substance to the presidential legacy, but when well employed, such a principle becomes a hallmark of presidential leadership.

In 1999, President Bill Clinton abstracted a common meaning from the war in Kosovo and his domestic race initiative that could, first, tie various issues together in a meaningful whole and, second, resonate with an interpretative framework with which the American public was already familiar. I argue that a combination of several interpretive tools cooperated to align apparently disparate events into a comprehensive whole, producing an interpretive schema that in the short term made certain actions or policies appear as logical moral imperatives for a nation striving toward virtue. ${ }^{3}$ In the long term, each new policy became part of a larger, overarching vision, a vision that Clinton claims had been the crux of his agenda since the beginning of his presidency, perhaps since his boyhood. In so doing, Clinton paints an alternative legacy for himself, offers the Democratic Party (and future presidential candidate Al Gore) a saving identity, and asks the American people to prefigure a new American community.

\section{Framing, Interpretation, and Identity}

In social psychology literature, "framing" is related to a rejuvenated concern with cultural issues. Derived from bodies of literature in phenomenological sociology and cognitive psychology, framing is, in its basic form, interpretation-a process of construing or imposing meaning from or on a given phenomenon. According to sociologist Alfred Schutz (1970), humans gain knowledge about the world by structuring their experiences into mental systems of relevances (levels of interest and priority) and typifications, that is, classifications. ${ }^{4}$ Over time, these mental processes 
result in a "stock of knowledge" that serves as a "scheme of interpretation" of one's past and present experiences, enables one to anticipate future experiences, and becomes "sedimented" with each new incorporated experience (Schutz, 1970, p. 74). Although this process may sound clear and concrete, it is anything but. Schutz (1970) emphasized that these stocks of knowledge are surrounded by "zones of various gradations of vagueness, obscurity, and ambiguity" (p. 74).

Building on the work of Schutz (1970) and others, Erving Goffman (1974, pp. 11-12) suggested that situations are defined according to principles of organization, which he terms "frames." These frameworks allow the user to locate, perceive, identify, and label an infinite number of occurrences even when the user is unaware of the frameworks' existence. In so doing, they render what would be seen as meaningless into something meaningful (Goffman, 1974, p. 21).

These ideas correlate with theories of information processing found in cognitive psychology literature and research, which suggest that making sense of the world requires scanning and selecting from one's experience, giving meaning to the incoming information by processing it through cognitive schema, and storing the information for future use (Holstein, 1985, Mandler, 1979, Neisser, 1976, Taylor \& Crocker, 1981). Such mental processing occurs in each individual, but because humans live in a social world with other individuals, they also occur between and among individuals. While each individual can and does structure and frame his or her experience, so also can she or he aid others in the process. No one can experience everything directly. We experience much of the world's phenomena through others' reports. We develop images and meanings about the things we have never directly experienced by allowing others (through "expert" accounts or ordinary gossip, for instance) to mediate or frame those images and meanings for us.

Hence, for every given experience or event, numerous interpretations, or "multiple realities," may abound (Goffman, 1974; Schutz, 1962). People often express considerable confusion about what and why something has happened or perceive experiences very differently from one another. This human need for order is akin to Kenneth Burke's (1965) concept of piety, which he defines as loyalty to a symbolic past that imbues a person with a "sense of what properly goes with what" and creates a desire to fit experiences together into a unified whole (p. 74). Framing helps to reduce or eliminate the plethora of interpretations and instead, by proffering one master frame or interpretation, creates congruity where once there was chaos. Fulfilling that need must often precede one's ability to act or to advocate an act with confidence.

Interestingly, Burke (1965) also likened interpretation to psychoanalytic therapy, a type of secular conversion that effects a cure by providing the patient with a new perspective and

\section{Coles 4}


terminology that replace the patient's "painful terminology of motives." According to Burke, this transformation

changes the entire nature of [the patient's] problem, rephrasing it in a form for which there is a solution....Sowe need not be surprised to find evidence that, in the secular rebirth engineered by the psychoanalytic seer, the processes of recovery from one's effective disorders are closely interwoven with a shifting of one's intellectualist convictions, one's terminology of cause, purpose, and prophecy. (p. 125)

However, framing is often more than just giving any meaning or a new meaning to an event. According to Diani and Eyerman (1992), a frame is a form of categorization whose aim is to transfer meaning from what is known to what is new or, as Allen, O' Loughlin, Jasperson, and Sullivan (1994) stated, a "process of placing information into a context of preconscious symbolism. The unconscious or preconscious references stimulate conscious judgments that might not have occurred if information had been framed... differently" (p. 267). For Snow and Benford (1988), the extent to which the frames strike a chord within dominant cultural beliefs-that is, the degree of cultural resonance attained by the frame-is positively correlated with success in attracting adherents. For instance, in the study of social movements (where most of the frame alignment literature is situated), Snow, Rochford, Worden, and Benford (1986) proposed that social movements must bring their politicized interpretations of events (i.e., their frames) into alignment with the preexisting frames of potential recruits. In other words, some of the activities, goals, and ideology of the social movement organization must be congruent with the individual's interests, values, or beliefs before his or her participation will occur. The authors give the example of the civil rights movement, whose activity and demands were placed in the context of inalienable rights and other liberal political concepts that had long defined and given legitimacy to (i.e., resonated with) the American polity. Such framing helped some observers not only to understand but more important to passively accept, and perhaps actively support, activity to which they previously may not have been exposed or to which they might have been adverse.

Frame alignment is not only concerned with aligning the meanings of the event with the meanings already in the minds of the audience, creating cultural resonance, but also with aligning the meanings of several, apparently unrelated, events to each other. In real life, no event occurs in a vacuum. Life is an accumulation of one event on another, although some are more salient than others. On occasion, it appears at least rhetorically necessary to reveal or create interpretative connections among apparently disparate events. In this discursive situation, frame alignment acts much like a pool rack that gathers the individually dispersed balls into a single coherent triangle.

\section{Coles 5}


Last, although most of the sociological literature on framing has emphasized its resource-building benefits (i.e., the effects on recruitment and/or public support primarily), framing activity also inherently involves identity construction. Most of the literature to date has focused on framing's role in the collective identity of social movements (Benford, 1993; Coles, 1999; Coy \& Woehrle, 1996; Hunt, Benford, \& Snow, 1994). However, I will argue here that it applies just as well to the collective identity of a political party or a nation and, more important, to individual identity building.

The close association between collective identity and framing lies in the way adherents of the frame think about themselves and by how shared experiences are interpreted (Johnston, Larana, \& Gusfield, 1994). When people organize themselves around a common identity (such as that of a social movement, political party, or nation), they may act as social laboratories, advocating and perhaps testing new ways of life, prefiguring new forms of community (Carroll, 1992).

Moreover, although frame alignment can successfully make meaningful connections among various events and policies_enough to enable the public to make sense of the plethora of political happenings, act in accordance with those shared understandings, and develop a group identity-alone it may not be sufficient to build an individual's presidential legacy. A legacy must have a sense of history - a sense of being passed down from one generation to another; it must have a biography.

The growing literature on the concept of "biographing" stems from the social constructionist approach and suggests that, similar to framing, biographing is the management of consistency and continuity of life experiences (Gubrium, Holstein, \& Buckholdt, 1994). As such, producing an integrated and meaningful interpretive biographical framework requires ongoing interpretation and reinterpretation of the events in one's life. The practice and form of the interpretation are influenced, although not determined, by the social context and representational resources at hand.

Biographing involves consideration of one's past for some purpose, highlighting the defining aspects of one's past in such a way to frame and organize one's character and actions into a story that makes sense in light of the present. This comports well with establishing a legacy, a story of what one's life and actions have been all about and, hence, of what one can bequest to his or her successor.

Bill Clinton's discourse, during the period addressed, ties numerous events and policies together under one umbrella of meaning, which helps the public understand those events. But Clinton does not stop there; he takes that meaning and locates its roots not only in the past 6 
years of his presidency but also in the early days of boyhood in the South. By doing so, he offers an alternative interpretation of his life and life work to the public and future presidential historians.

\section{The Rhetorical Situation}

Any rhetorical strategy is only consciously planned to a limited extent. Rhetorical form and content is frequently constrained by events beyond the control of the speaker, and rhetoric must, if success is its goal, adapt to and accommodate these events. Moreover, the essence of any frame is necessarily a simplification of a complex issue. To be successful, it cannot be ridiculously simple, and it must, as mentioned before, resonate with a sufficiently broad constituency.

The race issue has been salient in America throughout the country's history, no less today than during the peak of the civil rights movement or during slavery. ${ }^{5}$ Race issues have adapted to include racial-ethnic groups other than the original Native Americans, African Americans, and European Americans. Legal reforms since the 1960s, controversial in themselves, reduced some disparities among the races but left the most fundamental disparities (e.g., defacto residential and school segregation), especially among Native and African Americans, untouched. Discomfort, resentment, and anger are frequently near the surface when issues of race are discussed. Race issues resonate across America, but in this case, Clinton was aided even more by the occurrence of several incidents that make a race-related frame reverberate with the American public.

In June 1997, when the political scene was relatively quiet, Clinton had formed the President's Advisory Board on Race and charged the board with delineating the disparities among the races, initiating dialogue on race issues around the country, and locating examples of Americans working cooperatively to make progress on race relations. This 18-month project came to be called "the race initiative." 6 Toward the end of the initiative in June 1998, the saliency of unresolved race issues in this country was made painfully undeniable when James Byrd, a Black Texan, was dragged to his death by three White men.

About the time that the race initiative was coming to an ignominious end, the Bosnian situation likewise had simmered down without American military action, but it left many feeling that the United States had not done enough to prevent the numerous massacres. By the end of 1998, the Serbian government had turned its ethnic-cleansing policy from the Muslims in Bosnia to the Albanian Muslims in Kosovo. As the conflict in Kosovo heated up, it appeared that it would be a repeat of Bosnia in similarly bloody proportions. At the same time, it presented an opportunity for NATO to consolidate its power in Europe. Eventually, by February of 1999, when the results of negotiations between Slobodan Milosevic and the Kosovar Liberation Army in Rambouillet, France, suited neither NATO nor the Clinton administration, an undeclared war was nearing. 
So, for most of 1997 and 1998, the race initiative was treated primarily as a domestic policy, whereas the Bosnian and Kosovar conflicts generally rolled along a separate foreign policy track. During the 15-month race initiative, on occasion and in passing, Clinton mentioned several ethnic conflicts around the globe as examples of racial tension, ${ }^{7}$ but his focus clearly was on domestic unity and domestic policies, such as housing discrimination, economic opportunities, educational reforms, and small business loans. Similarly, although the term ethnic cleansing is used on occasion to describe the conflict in Kosovo (as it was in the Bosnian conflict), the conflict is much more frequently referred to as a "humanitarian catastrophe" or as a disaster threatening the stability of the region and an impediment to the goal of a united Europe. ${ }^{8}$ The two policy areas-the race initiative and Kosovo-were not linked together in any elaborated way until the president's personal and political interests were directly challenged.

On September 16, 1998, at a news conference with Czech President Havel, a journalist inquired of President Clinton,

Your initiative on race finishes this month, and your Press Secretary yesterday agreed that the race initiative isn't flying because of your current problems and it was bogged down in the muck and mire [referring to the Lewinsky affair]. Do you regret that your personal problems affected your potential legacy on race and that it may just, at best, be a band-aid approach to racism in America? (WCPD, 1998, No. 38, p. 1807

Put on the defensive, Clinton at first answered the question from the expected domestic policy perspective. He pointed out that legislation that would reduce the backlog of cases before the Equal Opportunity Commission and enforce antidiscrimination laws is currently before Congress. He mentioned that the administration is trying to create affirmative economic and educational opportunities in distressed inner-city and rural areas. But then, unexpectedly, he broadened the frame of reference to include a foreign policy element:

But I expect this [concern with bettering race relations] to be a central part of the work I do in the next two years. I expect this to be a central part of the work I do for the rest of my life. I think in the 21st century-when you go back to World War II, and you think about the part of the Nazi experience that was directed against the Jews, and you look all the way through the ensuing years, all the way to the end of this century, down to what we've seen in Rwanda, the Middle East, Northern Ireland, Bosnia, Kosovo, you name it, it will be incumbent upon the United States to be a force for tolerance and racial reconciliation for the foreseeable future. (WCPD, 1998, No. 38, p. 1808)

In that reply, the two policy tracks intersected. The failed race initiative collided with the need both for a prowar rhetoric and for a redefinition of his life work. Clinton, probably unwittingly at the time, began to interweave these and eventually other events (the murder of Matthew 
Shepard, which occurred in October 1998, and later the shooting in Littleton, Colorado, which occurred in April 1999) to produce a rhetorical tapestry that makes sense of the upcoming intervention in Kosovo and simultaneously establishes a legacy for himself, a mission for the people, and an identity for the Democrats. This encompassing rhetorical frame is most complete when his audience is composed of Democratic Party officials and members from around the country. A series of such meetings coincided with and, hence, helped shape these other rhetorical events in the spring of 1999 as the party prepared for the upcoming 2000 elections. Moreover, the fact that these events all occurred near the turn of the millennium adds a sense of historical import and urgency.

\section{The Frame of "Difference": A Psychological Problem With a Community Solution}

Because any particular life event is usually the result or manifestation of numerous, complicated factors, framing frequently necessitates a simplification or abstraction of meaning. The framer becomes involved in a process of abstracting certain qualities, supposedly the essence of the event (often informed by the special interests of the framer), from the given historical complexities (Burke, 1965, p. 107) of the event. Locating the essence or unitary principle of an event or events is a dynamic process, which underscores the importance of analyzing a period of discourse rather than one particular piece of rhetoric. Recognition and development of the principle occur over a period of time. The form of the principle may be influenced not only by the framer's own interests but by other signifying events that occur and by the perceived needs of the audience to which the rhetoric will be directed. This can be seen in Clinton's recharacterization of the race initiative over a period of a few months.

According to Carcasson and Rice's (1999, p. 258) analysis of Clinton's rhetoric on the 18-month race initiative, Clinton portrayed racial inequality as caused mostly by income inequality and gave short shrift to discrimination and bigotry as causative factors. However, the murders of James Byrd (occurring near the end of the initiative) and Matthew Shepard (occurring after the initiative had officially ended) and the imminent war in Kosovo redirected Clinton's rhetoric toward other causative concerns. After those events, Clinton's discourse focused more on the psychological determinant of racism and broadened racism to include ethnicity, sexual orientation, and religion-in other words, "difference."

Playing the role of Burke's psychoanalyst, Clinton first clearly diagnosed America's difficulties with difference as a psychological, pathological, even demonic problem. In a February 25, 1999, interview with Janet L. Cohen of the Armed Forces Television Network, Clinton 
established the fear of difference as a widespread but abnormal condition. He stated,

That psychological problem is at the bottom of a lot of this racial and ethnic hatred around the world. A lot of these groups themselves are deprived of opportunity. They've had economic adversity, had all kinds of diversity [sic], and a lot of them, frankly, are taught as groups that what gives meaning to their lives is that they're not a member of this other group; at least they've got somebody to look down on. (WCPD, 1999, No. 9, p. 359) ${ }^{9}$

Embedding racial conflict within a psychological approach implies that this fear of difference and its discriminatory outcomes are mostly an individual problem, manifested in those who have low self-esteem, have suffered economically, or have not been reared correctly. This insinuates that only a few bad apples are guilty of such behavior, and every individual is left to decide whether he or she is one of them. Simultaneously, Clinton still avoids discussion of systemic discrimination that is, perhaps unintentionally, built into the routines of various societal institutions or that is practiced among the wealthy or middle classes.

Overcoming this psychosis, the phobia of difference, became Clinton's master frame and unitary principle through the first half of 1999, which encompassed both the war in Kosovo and a series of Democratic National Committee meetings in preparation for upcoming elections. Other policies and missions then emanated from this unitary principle.

Clinton's rhetoric situates this global racial conundrum in the urgency of the coming $21 \mathrm{st}$ century and juxtaposes this fear of difference as a threat to progressive technological advances such as genetic engineering and the Internet and the prosperous world that could come from globalization. Clinton described this juxtaposition at the award ceremony for the National Teacher of the Year in April 1999:

It is truly ironic that here we stand on the verge of a new century and a new millennium - where education is more important than ever before, because we have this explosion in technology, drawing us closer to different people of different cultures, and our own country is becoming more diverse-we can imagine a future that is more prosperous and more peaceful and more interconnected, in a very human way, than ever before....andnowwe'vefound that that future was threatened by the oldest demon of human society, which is our fear of people who are different from us. (WCPD, 1999, No. 16, p. $677)^{10}$

To be consistent with the laws of physics, it would have been more accurate for Clinton to say that there has been an implosion in technology, as an explosion would hardly draw people together. In fact, a number of scholars (see Northcott, 1999) have charged that technology has indeed contributed to an atomization of American society. However, Clinton's discourse overlooks those ideas and the fact that the vast majority of the world's people lack access to technology or 
the Internet. Instead, Clinton incorporates language that describes technology (particularly the Internet) as forces of integration battling against the disintegrating forces posed by the world's obsession with difference. ${ }^{11}$

Pitting modern technology against the fear of difference creates a prophetic dualistic scheme in which technology represents goodness, progress, and promise, and the American obsession with difference represents evil, regression to the primitive, and a threat to the future. ${ }^{12}$ On occasion, Clinton portrays technology as a neutral phenomenon that can be used for good or evil, the latter being more likely when it is co-opted by people who follow their primitive urges and use the Internet to make terrorist bombs or racist Web sites. But more frequently, Clinton exonerates technology by repeating that ethnic groups around the world, particularly in Kosovo, are not fighting over the distribution of technology resources but over those old demons of difference. Painting this picture of a demonic psychosis gives the public a clear picture of the target problem, but Clinton must offer a positive alternative, a solution, for this frame to lead to proactive adherence rather than mere despair.

When Clinton had discussed race in the 15 months (June 1997-September 1998) that the Advisory Board on Race existed, he repeatedly reminded his audiences that by the middle of the 21st century, there would be no majority race in America. Expressing the fears of a few others before him (most notably Schlesinger, 1992), Clinton indicated that he was determined that rather than becoming many Americas, separate, unequal, and isolated, America should be one, united. ${ }^{13}$ Although Americans should appreciate, even celebrate, their differences, they more importantly should identify the common values that unite them. As a remedy to the fear of difference, he offered the "celebration of difference" but insisted that such a celebration be conducted within the more important embrace of commonalities as Americans. In fact, one of the duties of the race advisory board was to identify those American commonalities. However, by the start of the war in Kosovo in March 1999, the initiative had formally ended without success in that endeavor. ${ }^{14}$ So, Clinton used the same idea but widened the focus from American commonalities to universal commonalities. ${ }^{15}$

Unfortunately, the only characteristic that Clinton could identify as commonly held throughout the world was that we are all humans. Hence, "our common humanity" and the undelineated "what we have in common is more important than what divides us" became the sloganistic refrains of the 2-month war. ${ }^{16}$

However, by the middle of March 1999, Clinton offered more than just slogans to his audience. He invited them, particularly his Democratic listeners, into an elaborated description of community: 
We believe in a profound way in the idea of community—not some sappy, purely altruistic idea, but that we ourselves cannot have the lives we want unless we give our brothers and sisters round his country, and like-minded people all around the world the same opportunity. (WCPD, 1999, No. 12, p. 487)

With all of our increasing diversity in America, I wanted an America that really reaffirmed the idea of community, of belonging; the idea that none of us can pursue our individual destinies as fully on our own as we can when we want our neighbors to do well, too; and that there is some concrete benefit to the idea of community that goes beyond just feeling good about living in a country where you're not discriminated against because of some condition or predisposition or anything else that has nothing to do with the law and nothing to do with how your neighbors live their lives; and that what we have in common is more important than what divides us. (WCPD, 1999, No. 12, pp. 491-492) ${ }^{17}$

Clinton's focus on community resonates ${ }^{18}$ with a growing perception that America's cultural bent toward individualism has all but obliterated any sense of community (see Bellah, Madsen, Sullivan, Swidler, \& Tipton, 1985, 1991; Cowan, 1993; Etzioni, 1993; Jason, 1997; Lyon, 1989; Meyrowitz, 1985; and Shaffer \& Anundsen, 1993, just some of the writings addressing this concern). However, Clinton's concept suggested too that Americans simultaneously can have their individualism and community. Although he debased the idea of altruism as "sappy," he proffered the pursuit of self-interest as the incentive for each individual to seek her or his neighbor's well-being.

Noteworthy here are Mary Rousseau's (1991) writings on community. Analyzing Aristotle's musings on community, Rousseau (1991, p. 30) argued that community needs to be based on altruism (though not the sappy kind). Merely acknowledging our common human nature, which Aristotle also offered as a basis for community, is insufficient to produce altruism.

Rousseau contended that the concept of common humanity produces a false universalism that fails to accommodate the particularities of individuals, which is necessary for true altruism. "A common humanity," Rousseau wrote,

is a fine basis for civic equality, for granting the same human dignity and human rights to all members of the human species. It can be the basis for a certain sympathy by which we wish certain elements of human well-being to all of man-kind....We would then not discriminate in the bad sense, treating people differently on the basis of sex, color or age....But with such a universal sympathy, we would lose a more important and valuable kind of discrimination....Wewould not be able to recognize differences, and to treat different people differently, when it was appropriate to do so. In other words, if a common human nature is the only basis for one person's identification of another as his other self, then the friendship becomes abstract instead of real. (p. 30)

By failing to offer specific commonalities while trying to downplay Americans' differences, 
Clinton's rhetorical community offers platitudes rather than pragmatic ideas for implementation.

\section{Aligning Disparate Events}

Frame alignment, the gathering in of unrelated events or policies into one master frame, can be done indirectly or directly. Indirectly, alignment is accomplished by merely transitioning from one topic to another or intermingling topics in any given speech. For instance, Clinton often stated that he "is now going to say a few words about Kosovo," but his next three paragraphs would be about difference and hate crimes. In a couple of speeches, Clinton even relied on cognitive information-processing theory to make the connection. Sounding more like an academician than a politician, Clinton explained that the human tendency to devise mental categories that aid in comprehending human phenomena should be seen only as a tool and not in itself the truth. To think in such categorical terms, he suggested, only sets up false choices between domestic policy and foreign policy and false divisions among people. ${ }^{19}$

For the most part, Clinton's framing relies on this indirect approach. Speaking to a Democratic National Committee meeting in Washington in March 1999, 2 days before U.S. air strikes on Serbia began, he aligned support for his policy in Kosovo with support for the now-defunct race initiative and its attendant policies.

That's [the world being obsessed with holding others down] why I think it's important that we continue the President's Initiative on Race, which we're doing; why I think it's important that we pass the employment nondiscrimination act and the hate crimes law that I put before the Congress; why I think it's important we stand up against ethnic cleansing. (WCPD, 1999, No. 12, p. 505)

The subtle confluence of issues ties them together into one related framework, in which support for one policy implies support for another, and the critique of ethnic cleansing implies the critique of American ethnic divisions.

But occasionally, the president overtly and directly makes the connections for people, often transitioning from one topic to an apparently unrelated topic by asking, "What does this have to do with that?" For instance, speaking in April 1999 at a Majority 2000 luncheon in Dearborn, Michigan, Clinton discussed social security, education, and other domestic policies and then said, "I want to tell you how this business in Kosovo fits with all the other things...."20

Eventually, in remarks at a reception in New York City, Clinton suggested that the three remaining challenges of building the global society of the 21 st century are developing a financial system, guarding the environment, and going "to the heart in country after country after country of this dark compulsion people have to hate and fight and kill each other because of their religious, 
their racial, their cultural, or their other differences" (WCPD, 1998, No. 42, p. 2038). In other words, Clinton had taken his failing race initiative abroad, where fighting racial discrimination is less constrained by the need for persuasive dialogue and slow-moving congressional legislation but rather where one can fight the fear of difference with bombs and bullets.

But Kosovo was not the only event that became aligned with the race initiative. On October 10, 1998, Matthew Shepard, a gay college student in Laramie, Wyoming, was brutally beaten to death. Clinton remarked to the public:

One thing must remain clear: Hate and prejudice are not American values. I hope that... Americans will once again search their hearts and do what they can to reduce their own fear and anxiety and anger at people who are different. (WCPD, 1998, No. 42, p. 2032)

Two days after the Shepard murder, Clinton spoke at a reception for the Democratic gubernatorial candidate of New York, where he described New York as a city with remarkable diversity where all kinds of people have the chance to live out their dreams. However, Clinton pointed out, such is not the case all over the world. In Kosovo, in the Middle East, and other places around the world, people are held back or crushed because others are "so animated by fear and their compulsive need to look down on others that whole nations are kept from becoming what they ought to be" (WCPD, 1998, No. 42, p. 2037). Lest Americans think they have already overcome this universal human condition, Clinton alluded to Matthew Shepard and reminded the country that "America cannot do good in the world unless America is good at home" (WCPD, 1998, No. 42, p. 2038).

Then, on April 20, 1999, a multiple shooting at Columbine High School in Littleton, Colorado, grabbed the attention of Americans across the country. Initially, the shooting was portrayed within the old frame of school violence and its attendant policies of gun control and media regulation. However, soon some news reports indicated that the students who did the shooting had been teased and ostracized by some of their peers because of their lack of athletic prowess and the way they dressed. In turn, the victims became perpetrators by finding someone to target because of his differences (one of the 12 students killed was an African American boy). Hence, by May 14 through May 16, 1999, in another series of speeches to Democratic National Committee luncheons and dinners, ${ }^{21}$ Clinton aligned Littleton with Kosovo, the James Byrd and Matthew Shepard cases, and the policies of the Hate Crimes Act, Brady Bill (gun control) modifications, the Employment Nondiscrimination Act, and Timothy McVeigh's bombing of the federal building in Oklahoma. The frame of difference was bursting at the seams. ${ }^{22}$ 


\section{Effects of Clinton's Frame Alignment}

Three main effects arise from this frame alignment process. First, focusing on one frame inevitably leads people to overlook alternatives at numerous political levels. Although I do not mean to imply that this was Clinton's intention, going to war does shift the public focus from his personal morality. It reminds the public that Clinton is busy fulfilling his important presidential duties, which extend far beyond the activities that take place in his office. It also implies that, even with personal weaknesses, one can effectively perform stately tasks.

Second, acting on the various policies related to each large issue becomes both a moral imperative in the process of overcoming racism. At a March 30, 1999, electronics industry dinner, after describing how the psychological fear of difference manifested itself in the Balkans, talking about the deaths of James Byrd and Matthew Shepard, and reiterating the slogans of "celebrating our differences" and "our common humanity," Clinton concluded, "So I ask all of you tonight to support what the United States and our 18 other NATO allies are trying to do in the Balkans" (WCPD, 1999, No. 13, p. 540). Likewise, in an April 6, 1999, speech on the proposed Hate Crimes Prevention Act, Clinton reviewed the psychology exhibited in Kosovo and concluded that this is why passage of the hate crimes bill is so important (WCPD, 1999, No. 14, p. 587590).

Clinton's discourse also uses America's existing racial diversity as a reason to support the military campaign in Kosovo. First, Clinton defined the war's supporters as a diverse group of people. ${ }^{23}$ For instance, he defined NATO as a coalition of diverse nations, representing 780 million people of various religions, ethnicities, and races (WCPD, 1999, No. 17, p. 710). Beginning in the May 1999 series of speeches to Democratic National Committees, Clinton reiterated a story about a Native American group's visit to the White House. They and the president sat in a circle on the White House floor together, and one of the young American Indians stated how proud he would be to serve in Kosovo to prevent a genocide similar to that which occurred to Native Americans in the United States. ${ }^{24}$ In another speech to New York's Democratic National Committee, Clinton added that even American Jews were for the war in Kosovo, the implication being that because those being ethnically cleansed in Kosovo were Muslims, Jewish support might not normally be forthcoming (WCPD, 1999, No. 20, p. 943). At a Sons of Italy dinner on May 22. Clinton told a story of a Polish soldier in Kosovo and delineated the types of support the country of Italy is giving to the war effort (WCPD, 1999, No. 21, p. 970). Speaking on Memorial Day, Clinton reminded the audience at Arlington National Cemetery "how fitting it is that we are standing against ethnic cleansing with our wonderful myriad, rainbow, multiethnic military" (WCPD, 1999, No. 22, p. 1008). This diversity of support lends credibility to U.S. policy. If people from all these various backgrounds and varied interests support the war, how could any American 
not?

Last but not least, Clinton's master frame provides a vision for the American people, an identity for the Democratic Party as it begins to form its platform and recruit its various candidates for the upcoming national elections, and a legacy for himself. All three of these radiate from the unifying vision Clinton concocts of the future American community, where no one can succeed unless his or her neighbors also succeed.

In presenting the victory of community over the fear of difference, Clinton asks the American people to envision a new form of American society. Clinton's vision offers Americans an escape from a year of events that viscerally remind Americans that they are far from perfect. It offers them a new lens by which to view themselves not as passive victims of this psychological demon that appears to have plagued human history but as change agents, or secular exorcists, in overcoming this battle between the forces of progress and integration and the forces of regression and disintegration. In the sense that Clinton presents this vision not as a portrait of how America currently is but rather as what it could be in the 21st century, Clinton is also offering the country a mission. For instance, after talking about Kosovo to the audience at the White House's Seventh Millenium Evening, Clinton charged the audience with building a community that can withstand the warped side of human nature. He said,

Our challenge now, and the world's, is to harmonize diversity and integration, to build a richly textured fabric of civilization that will make the most of God's various gifts, and that will resist those who would tear that fabric apart by appealing to the dark recesses that often seem to lurk in even the strongest souls. (WCPD, 1999, No. 15, p. 633)

More specifically tying that challenge to specific policies, Clinton stated,

If we want America to do good around the world, we have to be good at home, first. Second, if we want to lead the world for peace and freedom, we've got to stand up against ethnic cleansing and mass killing. That's what Kosovo is about. ${ }^{25}$ America must set a model for the world. How Americans respond to both Littleton and Kosovo will say a lot about what kind of country we have for years to come. (WCPD, 1999, No. 20, p. 911)

This vision is offered as well to the Democratic Party as the basis of their platform, as the collective identity that distinguishes them from the Republican Party.

But the reason I'm here tonight, since l'm not running for anything anymore, is that I know that the reason we were able to follow good policies and do good things is that we started out with a vision and ideas that have now been embraced by my party, by the Democratic Party. And they make a difference. And they are different. They're different from what we were doing before, and 
they're certainly different-as you can tell if you just pick up the paper in the morning — from what the other party believes in Washington. (WCPD, 1999, No. 20, p. 926$)^{26}$

And last, this bundle of ideas about what America and the world should look like becomes Clinton's personal legacy. His discourse establishes this vision not only as something he hopes to pass on to America, but through biographing, Clinton implies that these ideas have been building throughout his life. First, Clinton makes certain it is understood by the public and party members that this vision was there since he first ran for president in 1991-1992. This vision is what his first 6 years had been founded on, and it has effectively changed the face of the country.

\begin{abstract}
When I came to California in 1991 and early '92, this was a very different place in a different country. People were divided and confused and drifting and frustrated. And I believed very strongly it was because we had no overriding vision for our future, no strategy to achieve it, no way, therefore, of pulling the American people together and getting us pointed in the right direction. And that's really why I got in the race for President....And the work of the last six years has largely been our combined efforts to take these ideas and that vision and hammer them into specific proposals. It's what animates our efforts today. (WCPD, 1999, No. 20, pp. 910-911) ${ }^{27}$
\end{abstract}

One would expect that a president would have this unified vision of what his administration and term(s) in office have been about, but on occasion, Clinton took the audience further back than the past 6 years. Often, in one-on-one interviews, Clinton referred to his boyhood and explained that growing up in the South with a single mother and grandparents and with interracial interactions all worked together to create this man with this particular vision. One of the first times he did this during this period was in an interview with Janet L. Cohen of the Armed Forces Television Network in February 1999. After discussing military pay and recruitment issues and Kosovo, Cohen asked the president why he has championed the rights of the underdog. Clinton replied,

My mother was widowed when I was born, and she was off studying to be a nurse. My grandparents raised me until I was 4 . My grandmother worked, as well as my grandfather; my grandmother was a nurse. So I had always been around women who had to work to make a contribution to their family's welfare. And so I think from early childhood I always was particularly sensitive to any kind of discrimination against women or just denial of opportunity. And I was always sort of rooting for them because of my mother and my grandmother.

And on the race thing, I think it was because of my grandfather and the fact that when I was a child he had a little grocery store in a predominantly black area of this little town we lived in. Most of the customers were black. And most of what I learned about people and human nature and treating everyone the same and also discrimination, I learned as a little boy just listening and watching and observing and being taught.

So, in a funny way, most... white southerners were at a disadvantage in dealing 
with the civil rights revolution because they were raised with more explicit racial prejudice. But some of us were actually at an advantage because we had more human contact with African-Americans before others did, and if we were lucky enough to have parents or grandparents that taught us differently, I think it made a difference. (WCPD, 1999, No. 9, p. $359)^{28}$

Coming at a time when his moral character and legacy was under question (refer to Note 1), Clinton in a sense acted as his own psychotherapist and took the opportunity to reinterpret himself. Although many were psychoanalyzing Clinton's past to answer the question "Why is he a philanderer?" Clinton selected certain experiences and memories (and ignored others) of his administration and childhood that together offered himself and the public an alternative definition of his persona and life work.

\section{Discussion}

In light of the facts that the Clinton administration produced the first budget surplus (estimated to be about $\$ 5.5$ trillion over the next 5 years) in recent years and that the country is currently experiencing the longest economic boom in the 20 th century, ${ }^{29}$ Clinton technically had other legacy options to offer the public. ${ }^{30}$ However, balanced budgets lack the moral impetus on which to construct a biography or build support for additional policies.

On the other hand, Clinton's portrait of America as a diverse community in which each individual's success is only possible or of value when it is contingent on another's success certainly poses a moral mission to a country long struggling with the tension between the individual's right to the pursuit of happiness and the community implied in a democracy of the people. The brother's keeper story, or the "he ain't heavy, he's my brother" theme, has been embedded in the mythology that America was a land welcoming the overburdened. Yet, the more diverse the country has become and the more income inequality has increased (Johnston, 1999) over the past three decades, the more difficult it has become to spell out exactly and pragmatically what those values would entail in terms of public policy. Clinton charged the American public and the Democratic Party with somehow finding a way to take every American along on the ride into the 21 st century and suggested a number of policies that would supposedly aid in achieving that end (i.e., gun control, hate crimes, fighting against ethnic cleansing, etc.).

In the short term, and pragmatically speaking, such a framework got him through the war in Kosovo with little American dissent (the fact that he refused to use ground troops in Kosovo probably did not hurt either). Taking the race initiative abroad by stopping ethnic cleansing in the Balkans appeared easier to do and more morally urgent than solving racism here at home. Also, 
his spurt of speeches to Democratic Party members apparently persuaded more people to donate to the party (Seelye, 1999). However, in terms of the specific pieces of legislation that were piggybacked onto this framework, outcomes were mixed. Congress failed to pass the tighter gun control act, leaving the gun show loophole open, and the federal Hate Crimes Act, which would add sexual orientation, sex, and disability to hate crimes laws.

Moreover, it is dubious whether the American public adopted the mission for the long term or whether it believes the Democratic Party has such a distinct identity from the Republican Party. In recent years, declining voter turnout and the growing interest in third-party politics seem to indicate a feeling that the Democratic and Republican Parties appear as two sides of the same coin. Indeed, it is somewhat ironic that Clinton, who earned a reputation for bringing the Democratic Party closer to the political center by co-opting a number of Republican issues, such as crime, a balanced budget, and welfare reform (McManus, 1998), is the same person offering the Democratic Party a distinguishing identity. More likely, Clinton's discourse left the dramaturgical presidency intact, leaving Washington insiders fascinated with the blow-by-blow account of partisan and personal ambition but leaving the public wondering if either party has any interest in the public good.

On a more intangible level, Clinton's rhetoric tapped into several long-standing cultural conflicts as well. These so-called culture wars frequently occur between the extreme ends of the two political parties. According to James Hunter (1999), these battles have largely, though not entirely, been fought over public issues concerned with private matters, such as abortion or homosexuality. However, underlying these battles over specific issues is a more important "war for the nation's soul" (presidential candidate Pat Buchanan, quoted in Williams, 1999) or "struggle over who will shape the nation's identity" (Hunter, 1999, p. 18).

In large part, Clinton's rhetoric attempted to accommodate, or find a compromise between (or pejoratively speaking, attempted to ride the fence on), both sides of the debates. Perhaps in a desire to please as many factions as he could, or in keeping with the American optimism that one can have it all, Clinton's discourse essentially chose both individualism and community, both pluralism and monoculturalism.

In addition, the timing of Clinton's frame alignment came when his personal morality was under question. His sexual fidelity and lying had become the focus not only of conservatives who pursued impeachment but also — through seemingly unending hours of broadcasted grand jury videotapes and online viewing of the graphic independent counsel's report-of the country, which then entered a debate over the role of personal morality in the political context. In practical terms, pulling disparate but pressing and salient issues together into one frame helped overshadow the 
repercussions of the Lewinsky scandal. Clinton's discourse resisted the portrayal of himself and his administration as one of dalliance. Instead, the reframed discourse reflexively redefined Clinton by conferring seriousness and depth of character to himself. His concern with race and community in America became the main staple of his identity, embedded there through early childhood experiences. Hence, the incidents of sexual promiscuity became not his primary identity but rather detours from his essential character. Measure of the success of the newly constructed identity might be found in the fact that Clinton's job approval rating remained above $60 \%$ for most of this period (Berke, 1999a; McManus, 1998; Nagourney \& Kagay, 1998).

Moreover, by shifting the limelight from these personal, though no longer private, concerns to the issue of overcoming difference and building community, Clinton refocused the discourse from, for lack of a better term, "micro morality" to "macro morality." Clinton's discourse and actions shifted the question from the simple and polarized "Should an immoral person be president?" (a question designed to fit the needs of poll takers) to a more complicated "To what extent does it matter if an immoral person is president?" By going to war and refocusing the discourse away from his personal morality to presidential issues, Clinton was essentially saying, "Regardless of whether I should be president, I am president, and I am doing the work of a president. Let's talk about this work instead." This refocusing suggests that in the bigger picture, racism, hate, poverty, and education, for instance, are also moral matters deserving more attention than any one individual's morality. Clinton's rhetoric about race and community, about leaving no one behind as we enter the 21st century, reminded the public that, in the process of erasing the false dichotomy between the personal and the political, issues of the common good are often diminished in a spectacle-oriented media culture, where frequently the adversarial human interest story, albeit here a presidential one, becomes the focal point, while history, social structure, and inequalities are elided (Edelman, 1988). ${ }^{31}$ To some extent, Clinton's rhetoric may have been effective in this regard, as the majority of the public, according to most surveys, did not think his personal morality was sufficient justification for a political impeachment. ${ }^{32}$

On the other hand, this is not to say that Clinton's discourse on race and war was intended to or succeeded in enlightening the public on the historical or structural aspects of these issues. Indeed, Clinton's focus on the psychological aspect of difference meant other reasons for conflict (domestic or foreign) - economics, politics, Western intervention, debt, and so forth—were ignored. Blame is focused on a warped human nature, not on structural elements. Bringing Kosovo into this psychological explanation implies that if one crazed individual-Milosevic (the human interest angle)—could be removed from power, the ethnic problems would be resolved. The psychological focus also assures Americans that racism is not only an American problem but 
is practiced around the world, perhaps to a greater degree. Americans can then feel better about themselves, put the domestic race initiative behind them, and focus for the time being on helping others who suffer from racism worse than theirs.

In sum, this study outlines the ways frame alignment processes can serve a variety of ends at one time. Here, they worked to build (or at least attempted to build) support for a variety of originally unconnected issues, which is the use that scholars usually attribute to frame alignment. But here also, frame alignment created a sense of mission and identity for a party and a nation and helped to construct a legacy for an outgoing president. In addition, I posed biographing, a social constructionist concept more commonly used in ethnographic studies of client-therapist discourse, as a frame alignment process that can be used in political discourse. This raises a number of questions for further research. Presidential public discourse generally presents few opportunities for most presidents to elaborate on their personal lives or childhood experiences; presidents normally refrain from personalizing public proclamations, speeches to Congress, declarations of war, and so forth. To what extent can biographing add to or subtract from the credibility of advocated policies or of the advocate? Can biographing, or frame alignment in general, in some paradoxical fashion effectively maintain the curiosity of the public through human interest but simultaneously focus the public on issues of social and common good? Because Clinton used biographing mostly in one-on-one interviews or in speeches to party members, the "appropriateness" of the context of biographing may very much determine its effectiveness. How much control can a public figure exert over his or her self-definition through the use of frame alignment processes? And to what extent can presidents or any public figure discursively determine how his or her legacy will be recorded in future historical texts?

This also brings us to a weakness in many rhetorical or discursive analyses and present here as well: Most such studies, if they measure the efficacy of rhetoric at all, do so by asking whether the discourse comported with established rhetorical devices and strategies rather than by measuring the effect of the rhetoric on the audience. To be sure, such measurements are difficult to ascertain in the real world where controlled experimental contexts cannot be created. Nevertheless, study of the impact and/or effectiveness of this particular framing performance would be enhanced by further long-term analyses of Democratic Party rhetoric to identify substantive changes that may be due to Clinton's discourse or by qualitative studies of local initiatives (such as community race dialogues or grassroots projects designed to enhance community relations ${ }^{33}$ )to determine their frequency and motivation. As to Clinton's legacy, the next glut of history textbooks and presidential biographies may be more telling, as the interpretative frameworks they offer of the Clinton presidency may have more long-term force in

\section{Coles 21}


shaping the Clinton legacy than anything Clinton himself may have said.

\section{Author}

Roberta L. Coles is an assistant professor in the Department of Social and Cultural Sciences at Marquette University. Some of her publications have appeared in the Sociological Quarterly, Sociological Spectrum, Michigan Journal of Community Service Learning, and Journal of Aging Studies.

\section{Notes}

1. For instance, on January 21, 1998, Jim Lehrer asked Clinton on the PBS News Hour, "What should the American people think about their President right now? You're going into...the last 3 years of your administration: you got all this controversy today" (Weekly Compilation of Presidential Documents [WCPD], 1998, No. 41, p. 113). On September 2, 1998, at a press conference with Russian President Boris Yeltsin, a UPI reporter asked, "Speaking of the challenges that we face as a nation...hasthereaction since your admission of a relationship with Ms. Lewinsky...givenyouany cause for concern that you may not be as effective as you should be in leading the country?" (WCPD, 1998, No. 36, p. 1691). On September 16, during a press conference with President Havel of Czechoslovakia, a reporter prodded, "What do you say to people who have said that you have lost all the moral authority to lead this Nation or to conduct foreign affairs?" (WCPD, 1998, No. 38, p. 1805). In a March 19, 1999, news conference, a reporter asked Clinton whether his legacy will be about lying (WCPD, 1999, No. 12, p. 479). And in a question-and-answer session with newspaper editors on April 15, 1999, a reporter inquired, "As you near the end of your second term in office and deal with such issues as the Balkans, what legacy do you believe you are leaving to the American public?" (WCPD, 1999, No. 15, p. 652).

2. For instance, "The Man Who Won't Say Why," an editorial in The Economist (May 22, 1999, p. 33) argued that Americans will yearn for a new president with some degree of reserve after Clinton. And "New York's Musical Chairs," an editorial in the May 29, 1999, issue of The Economist, argued that Hilary was too identified with what could increasingly be a "sleazy-looking lame-duck administration" (p. 30). See also Berke (1999a). Later in the year, see Berke (1999b) and Kohut (1999).

3. By using the term disparate, I do not intend to imply here that race relations in America and in the Balkans have no commonalities. Indeed, many of the same social, economic, and psychological factors are probably present in both situations. Moreover, at times race relations in 
one country can affect race relations in another. Frame alignment can often serve the purpose of educating people as to the real intersections of various superficially unrelated issues. However, the point here is that in this situation, Clinton's race initiative had not aspired to making those types of connections previously. It had focused only on domestic issues, and then only on race (not difference), until the war in Kosovo and the need for a Democratic Party identity and a legacy became salient.

4. See Schutz (1970, chap. 5, pp. 111-122).

5. See Goldzwig (1999). The articles in this special issue address various rhetorical strategies in regard to civil rights since World War I.

6. See Carcasson and Rice (1999) for an excellent analysis of the rhetorical components of the initiative.

7. Clinton sometimes listed various global ethnic conflicts, such as those in India, Northern Ireland, Rwanda, the Middle East, Russia, Bosnia, and Kosovo. See, for instance, "Opening Remarks in a Roundtable Discussion on Race in Akron, Ohio" (WCPD, Vol. 33, No. 49, pp. 1957-1959); "Remarks to the 75th Annual Convention of the American Federation of Teachers in New Orleans, Louisiana" (WCPD, 1998, No. 30, pp. 1432-1439); and "Remarks to President's Advisory Board on Race" (WCPD, 1998, No. 39, pp. 1834-1838).

8. This frame was not eliminated but was moved to a peripheral position, particularly in the speeches to the Democratic audiences. In his speeches specifically related to Kosovo, Clinton frequently continued to define Kosovo less in its ethnic framework and more in its humanitarian and regional framework. In addition, as the conflict in Kosovo built during fall 1998 and Clinton was forced to discuss the conflict more frequently, he often apologized whenever he had to mention it within a nonrelated speech, again suggesting that Clinton originally did not see Kosovo as linked to other issues. For instance, on October 6, 1998, during remarks to the annual meeting of the IMF and World Bank, he said, "Before I begin my remarks, I hope you will permit me to say a few words about another issue of real concern to the international community...thesubject of Kosovo" (WCPD, 1998, No. 41, p. 1983). In his remarks on health maintenance organizations later in the day, he said, "Since this is the only time l'll have to talk to the press for the next several hours, I hope you will indulge me for a moment while I make a few comments about the present situation in Kosovo" (WCPD, 1998, No. 41, p. 2008).

9. See similar statements at "Remarks at the Legislative Convention of the American Federation of State, County and Municipal Employees" (WCPD, 1999, No. 12, p. 505); "Remarks on the Proposed 'Hate Crimes Prevention Act' " (WCPD, 1999, No. 14, pp. 588-589); "Remarks at a Majority 2000 Luncheon in Dearborn, Michigan" (WCPD, 1999, No. 15, p. 663); "Remarks in a 
Roundtable Discussion With Students on Violence in Schools at T.C. Williams High School in Alexandria, Virginia" (WCPD, 1999, No. 16, p. 692); and "Remarks in a Discussion Entitled 'The Third Way: Progressive Governance for the 21st Century" " (WCPD, 1999, No. 17, p. 738).

10. See similar quotations in, for instance, "Remarks at a Democratic National Committee Dinner" (WCPD, 1999, No. 12, p. 505); "Remarks on the Proposed 'Hate Crimes Prevention Act'" (WCPD, 1999, No. 14, p. 589); "Remarks at the Seventh Millennium Evening at the White House" (WCPD, 1999, No. 15, p. 632); "Remarks and a Question-and-Answer Session With the American Society of Newspaper Editors in San Francisco, California" (WCPD, 1999, No. 15, p. 646); and "Remarks at a Union of American Hebrew Congregations Dinner Honoring Rabbi David Saperstein" (WCPD, 1999, No. 17, p. 743).

11. See, for instance, "Remarks at a Democratic National Committee Dinner" (WCPD, 1999, No. 12, p. 511); "Remarks at the Seventh Millennium Evening at the White House" (WCPD, 1999, No. 15, p. 632); and "Remarks at a Question-and-Answer Session With the American Society of Newspaper Editors in San Francisco, California" (WCPD, No. 15, p. 646).

12. Prophetic dualism is a rhetorical strategy that essentially divides the world into two camps-one good, the other evil. The division allows for no neutrality or compromise, only total victory. For a more elaborate discussion of prophetic dualism, see the work of Wander (1984).

13. See, for instance, "Remarks at the University of California-San Diego Commencement Ceremony in LaJolla, California" (WCPD, Vol. 33, No. 25, pp. 877, 882); "Commencement Address at Portland State University in Portland, Oregon" (WCPD, Vol. 33, No. 25, p. 1122); and "Remarks to the 75th Annual Convention of the American Federations of Teachers in New Orleans, Louisiana" (WCPD, 1998, No. 30, p. 1434).

14. See Carcasson and Rice (1999), who argued that the race initiative was a failure in a number of ways. Although Clinton (1996) had mentioned in his book Between Hope and History support of the Declaration of Independence and the Constitution as ideals that Americans have in common, that theme was rarely mentioned in his public rhetoric during this period.

15. Although I do not imply that this was Clinton's intention, universal commonalities are more progressive than American commonalities if viewed from a Marxist perspective. Nationalism, in one sense just a higher form of tribalism, still pits one country against another.

16. See, for instance, "Remarks at the National Governors' Association Meeting" (WCPD, 1999, No. 8, pp. 282-283); "Remarks at a Democratic National Committee Dinner" (WCPD, 1999, No. 12, p. 502); "Remarks at a Democratic National Committee Dinner" (WCPD, 1999, No. 12, p. 511); and "Videotape Address to the Serbian People" (WCPD, 1999, No. 12, p. 521).

17. These descriptions occurred most frequently in a series of speeches at Democratic 
National Committee luncheons and dinners, which began in March 1999 (WCPD, 1999, Nos. 11 and 12), just a few days before the United States begins air strikes in Serbia. However, the bulk of them occurred in May 1999 (WCPD, 1999, Nos. 19 and 20), during the peak of the war.

18. Clinton himself is aware of the need for his rhetoric to resonate with the public. He stated specifically that the Democratic Party needs to take a message to the people that "resonates with them." See "Remarks at a Democratic National Committee Reception" (WCPD, 1999, No. 12, p. 485); "Remarks at a Democratic National Committee Dinner in Portola Valley, California" (WCPD, 1999, No. 20, p. 903).

19. See "Remarks at a Democratic National Committee Dinner" (WCPD, 1999, No. 12, p. 502); "Remarks at a Union of American Hebrew Congregations Dinner Honoring Rabbi David Saperstein" (WCPD, 1999, No. 17, pp. 744-745).

20. "Remarks at a Majority 2000 Luncheon in Dearborn, Michigan" (WCPD, 1999, No. 15, pp. 658-659). See also "Remarks at a Union of American Hebrew Congregations Dinner Honoring Rabbi David Saperstein" (WCPD, 1999, No. 17, p. 743); "Remarks at a Democratic National Committee Luncheon in Seattle, Washington" (WCPD, 1999, No. 20, p. 899); "Remarks at a Democratic National Committee Dinner in Portola Valley, California" (WCPD, 1999, No. 20, p. 905); and "Remarks at a Democratic Congressional and Senate Campaign Committees Dinner in Beverly Hills, California" (WCPD, 1999, No. 20, p. 913).

21. These are all located in WCPD (1999, No. 20).

22. In early May 1999, Clinton tried to incorporate the tornadoes in Oklahoma into his framework, but he failed to find an element of difference or diversity with which to make the connection. It is incorporated only in his May 7, 1999, speeches that took place in Texas.

23. This is apparently a common technique in war rhetoric, as it was also used by Bush in his prowar discourse in the Persian Gulf War. He frequently identified the allied coalition as composed of nations of various races, ethnicities, religions, forms of government, and so forth (see Coles, 1998).

24. See "Remarks at a Democratic National Committee Luncheon in Seattle, Washington" (WCPD, 1999, No. 20, p. 900); "Remarks at a Congressional and Senate Campaign Committees Dinner in Beverly Hills, California" (WCPD, 1999, No. 20, p. 915); "Remarks at a Democratic National Committee Dinner in Las Vegas" (WCPD, 1999, No. 20, p. 928); "Remarks at a Democratic National Committee Luncheon in New York City" (WCPD, 1999, No. 20, p. 943); and "Remarks at the Sons of Italy Foundation Dinner" (WCPD, 1999, No. 21, p. 970).

25. "Remarks at a Democratic National Committee Dinner in Las Vegas" (WCPD, 1999, No. 20, p. 927). See also "Remarks at a Democratic National Campaign Dinner" (WCPD, 1999, No. 12, 
p. 506) and "Remarks at a Democratic Senatorial Campaign Committees Dinner" (WCPD, 1999, No. 19 , p. 877).

26. Similarly, see "Remarks at a Democratic National Committee Dinner" (WCPD, 1999, No. 12, p. 505); "Remarks at a Democratic National Committee Dinner in Austin" (WCPD, 1999, No. 19, p. 847); and "Remarks at a Democratic National Committee Reception in Las Vegas, Nevada" (WCPD, 1999, No. 20, p. 923).

27. Similarly, see "Remarks at the Legislative Convention of the American Federation of State, County, and Municipal Employees" (WCPD, 1999, No. 12, pp. 491492); "Remarks at a Democratic National Committee Luncheon in Houston, Texas" (WCPD, 1999, No. 19, p. 841); "Remarks at a Democratic National Committee Luncheon in Seattle, Washington" (WCPD, 1999, No. 20, p. 897); "Remarks at a Democratic National Committee Dinner in Portola Valley, California" (WCPD, 1999, No. 20, p. 903); "Remarks at a Democratic National Committee Luncheon in San Diego, California" (WCPD, 1999, No. 20, p. 916); "Remarks at a Democratic National Committee Reception in Las Vegas, Nevada" (WCPD, 1999, No. 20, p. 923); "Remarks at a Democratic National Committee Luncheon in New York City" (WCPD, 1999, No. 20, p. 944); and "Remarks at the White House Community Empowerment Conference in Edinburg, Texas" (WCPD, 1999, No. 21, p. 986).

28. That quote is Clinton's most extensive example of biographing from his boyhood, but he repeated abridged versions in an "Interview With Dan Rather of CBS News" (WCPD, 1999, No. 13, p. 553); "Remarks on the Proposed Hate Crimes Prevention Act" (WCPD, 1999, No. 14, p. 588); and in "Remarks at the Majority 2000 Luncheon in Dearborn, Michigan" (WCPD, 1999, No. 15, p. 661).

29. The U.S. economy reached a growth rate of $6.1 \%$ in the last quarter of 1998 . See Uchitelle (1999) and Broder and Sanger (1999).

30. Some felt he could claim the environment as a legacy as well because Clinton's administration had fought for protection of Florida's Everglades, Utah's red rock, and California's redwood forest. See the The New York Times editorial, "A Forest Legacy?" (October 18, 1999, at http://www.nytimes.com). Also, an article (Deans, 1999) in the Wisconsin State Journal suggested that Clinton's legacy was his work toward building a global economy (written during the Seattle protests over the World Trade Organization, it was not, however, framed as a positive legacy).

31. See also Stabile (1995), whose study of the television program Roseanne argued that conceptualizing cultural change as a battle between conservative/recuperative or progressive/resistant ideologies limits understanding of economic factors that may play a more 
important role in determining the apparent cultural modifications.

32. According to polls, close to $60 \%$ did not think Clinton should be impeached. However, a similar percentage thought that if he were impeached, he should just resign. See "Relying on Polls Could Be a Dangerous Strategy for Clinton to Follow" (Boston Globe, December 16, 1998; accessed online at http://www.jsonline.com).

33. For instance, in Madison, Wisconsin, several small groups of individuals began meeting to discuss race relations due to the president's focus on race. Another Madison organization, Madison Urban Ministries, began a campaign of lawn signs that read "Let Your Light Shine. Fight Racism." Although the "success" of such groups would be difficult to define and measure, they nevertheless were a response to Clinton's rhetoric. The publication Pathways to One America in the 21st Century: Promising Practices for Racial Reconciliation, written by the President's Advisory Board on Race (and accessed online through http:|lwww.whitehouse.gov) reviews some local efforts in regard to race issues started during the initiative, but a systematic study that looked at community-building initiatives as well would be helpful. The two sets of grassroots initiatives (race dialogues and community-building initiatives) may or may not intersect. Some have argued that the past era of close-knit communities that Americans hanker for existed because they were racially homogenous and exclusive communities, building their closeness on keeping others out. See Shaffer and Anundsen (1993) for instance.

\section{References}

Allen, B., O'Loughlin, P., Jasperson, A., \& Sullivan J. L. (1994). The media and the Gulf War: Framing, priming, and the spiral of silence. Polity, 27(2), 255-284.

Anderson, B. (1983). Imagined communities: Reflections on the origin and spread of nationalism. London: Verso.

Bellah, R., Madsen, R., Sullivan, W., Swidler, A., \& Tipton, S. (1985). Habits of the heart: Individualism and commitment in American life. Berkeley: University of California Press.

Bellah, R., Madsen, R., Sullivan, W., Swidler, A., \& Tipton, S. (1991). The good society.New York: Knopf.

Benford, R. D. (1993). Frame disputes within the nuclear disarmament movement. Social Forces, 71(3), 677-701.

Berke, R. L. (1999a, February 17). Lewinsky ordeal may have put Gore on firmer ground for 2000 [online]. The New York Times. Available: http://www.nytimes.com

Berke, R. L. (1999b, March 6). Political memo: Weighing the vice presidential factor in Gore's feeble showing in the polls [online]. The New York Times. Available: http://

Coles 27 
www.nytimes.com

Broder, J. M., \& Sanger, D. E. (1999, May 13). A new economic team: The resignation [online]. The New York Times. Available: http://www.nytimes.com

Browne, S. H. (1991). Edmund Burke's Discontents and the interpretation of political culture. Quarterly Journal of Speech, 77, 53-66.

Burke, K. (1965). Permanence and change: An anatomy of purpose (2nd ed.). New York: Bobbs-Merrill.

Burke, K. (1969). A grammar of motives. Berkeley: University of California Press.

Carcasson, M., \& Rice, M. F. (1999). The promise and failure of President Clinton's race initiative of 1997-1998: A rhetorical perspective. Rhetoric and Public Affairs, 2(2), 243-274.

Carroll, W. K. (1992). Introduction: Social movements and counter hegemony in a Canadian context. In W. K. Carroll (Ed.), Organizing dissent: Contemporary social movements in theory and practice (pp. 1-21). Toronto, Canada: Garamond.

Ceaser, J. W., Thurow, G. E., Tulis, J., \& Bessette, J. M. (1981). The rise of the rhetorical presidency. Presidential Studies Quarterly, 11(2), 158-171.

Clinton, W. J. (1996). Between hope and history: Meeting America's challenge for the 21 st century. New York: Times Books.

Coles, R. L. (1998). Peaceniks and warmongers' framing fracas on the home front: Dominant and opposition discourse interaction during the Persian Gulf crisis. Sociological Quarterly, 39(3), 369-391.

Coles, R. L. (1999). Odd folk and ordinary people: Collective identity disparities between peace groups in the Persian Gulf War. Sociological Spectrum, 19(3), 325-357.

Cowan, J. (1993). The common table: Reflections and meditations on community and spirituality in the workplace. New York: Harper Business.

Coy, P. G., \& Woehrle, L. M. (1996). Constructing identity and oppositional knowledge: The framing practices of the peace movement organizations during the Persian Gulf War. Sociological Spectrum, 16, 287-327.

Deans, B. (1999, December 5). Debate over global trade no longer left to the experts. Wisconsin State Journal, p. 1B.

Diani, M., \& Eyerman, R. (1992). The study of collective action: Introductory remarks. In M. Diani \& R. Eyerman (Eds.), Studying collective action (pp. 1-21). London: Sage. Edelman, M. (1988). Constructing the political spectacle. Chicago: University of Chicago Press.

Etzioni, A. (1993). The spirit of community. New York: Crown.

Goffman, E. (1974). Frame analysis. Cambridge, MA: Harvard University Press. 
Goldzwig, S. R. (Ed.). (1999). Special issue on civil rights in the postmodern era. Rhetoric and Public Affairs, 2(2).

Gubrium, J. F., Holstein, J. A., \& Buckholdt, D. R. (1994). Constructing the life course.New York: General Hall.

Holstein, J. A. (1985). Jurors' interpretations and jury decision-making. Law and Human Behavior, 9(1), 83-100.

Hunt, S. A., Benford, R. D., \& Snow, D. A. (1994). Identity fields: Framing processes and the social construction of movement identities. In E. Larana, H. Johnston, \& J. R. Gusfield (Eds.), New social movements: From ideology to identity (pp. 185-208). Philadelphia: Temple University Press.

Hunter, J. D. (1999). The culture wars reflect the polarization of American society. In M. E. Williams (Ed.), Culture wars: Opposing viewpoints (pp. 17-25). Farmington Hills, Ml: Greenhaven.

Jason, L. A. (1997). Community building: Values for a sustainable future. Westport, CT: Praeger. Johnston, D. C. (1999, September 5). Gap between rich and poor found substantially wider [online]. The New York Times. Available: http:Ilwww.nytimes.com

Johnston, H., Larana, E., \& Gusfield J. R. (1994). Identities, grievances and new social movements. In E. Larana, H. Johnston, \& J. R. Gusfield (Eds.), New social movements: From ideology to identity (pp. 3-35). Philadelphia: Temple University Press.

Kohut, A. (1999, August 5). A clear case of Clinton fatigue [online]. The New York Times. Available: http:Ilwww.nytimes.com

Lyon, L. (1989). The community in urban society. Lexington, MA: D. C. Heath. Mandler, J. (1979). Categorical and schematic organization in memory. In C. R. Puff (Ed.), Memory organization and structure (pp. 259-299). New York: Academic Press.

McManus, D. (1998, December 20). Impeachment will define Clinton's place in history. Los Angeles Times News Service. Reprinted in the Milwaukee Journal-Sentinel [online]. Available: http:Ilwww.jsonline.com

Meyrowitz, J. (1985). No sense of place: The impact of electronic media on social behavior. Oxford, UK: Oxford University Press.

Nagourney, A. (with Kagay, M. R.). (1998, December 21). Impeachment: The polls; public support for the president, and for closure, emerges unshaken [online]. The New York Times.

Available: http:Ilwww.nytimes.com

Neisser, U. (1976). Cognition and reality. New York: Freeman.

Northcott, A. (1999). Internet, community, and the technological way of being. Cultural Studies: A 
Research Volume, 4, 99-130.

Rousseau, M. F. (1991). Community: The tie that binds. New York: University Press of America. Schlesinger, A., Jr. (1992). The disuniting of America: Reflections on a multicultural society. New York: Norton.

Schutz, A. (1962). Symbol, reality and society. Collected papers (Vol. 1). The Hague, the Netherlands: Martinus Nijhoff.

Schutz, A. (1970). On phenomenology and social relations (H. R. Wagner, Ed.). Chicago: University of Chicago Press.

Seelye, K. Q. (1999, March 20). One consolation for Clinton: Democratic donations surge [online]. The New York Times. http:Ilwww.nytimes.com

Shaffer, C. R., \& Anundsen, K. (1993). Creating community anywhere: Finding support and connection in a fragmented world. New York: G. P. Putnam.

Slotkin, R. (1992). Gunfighter nation: The myth of the frontier in twentieth-century America. New York: Atheneum.

Snow, D. A., \& Benford, R. D. (1988). Ideology, frame resonance, and participant mobilization. In B. Klandermans, H. Kriesi, \& S. Tarrow (Eds.), From structure to action: Comparing social movement research across cultures (pp. 197-217). International Social Movement Research (Vol. 1). Greenwich, CT: JAI.

Snow, D. A., Rochford, E. B., Jr., Worden, S. K., \& Benford, R. D. (1986). Frame alignment processes, micromobilization and movement participation. American Sociological Review, 51, 464-481.

Stabile, C. (1995). Resistance, recuperation, and reflexivity: The limits of a paradigm. Critical Studies in Mass Communication, 12, 403-422. Stuckey, M. E. (1991). The president as interpreter-in-chief. Chatham, NJ: Chatham House. Taylor, S., \& Crocker, J. (1981). Schematic bases of information processing. In T. Higgins, C. Herman, \& M. Zanna (Eds.), Social cognition: The Ontario symposium (Vol. 1, pp. 89-134). Hillsdale, NJ: Lawrence Erlbaum.

Tulis, J. K. (1987). The rhetorical presidency. Princeton, NJ: Princeton University Press.

Uchitelle, L. (1999, October 29). Strong summer apt to propel economic boom to a record [online]. The New York Times. Available: http://www.nytimes.com

Wander, P. (1984). The rhetoric of American foreign policy, Quarterly Journal of Speech, 70(4), 339-361.

Weekly compilation of presidential documents. (1998). Volume 34 (Nos. 1-52). Washington, DC: Government Printing Office.

Coles 30 
Weekly compilation of presidential documents. (1999). Volume 35 (Nos. 1-52). Washington, DC: Government Printing Office.

Williams, R. H. (1999). Culture wars are largely rhetorical. In M. E. Williams (Ed.), Culture wars: Opposing viewpoints (pp. 26-35). Farmington Hills, MI: Greenhaven. 